\title{
Role of Ministerial media arms during COVID-19 in Malaysia
}

\author{
Gharawi Mohammed ${ }^{1}$, AZMAN Bidin ${ }^{2}$ Ahmed Badawy ${ }^{3 *}$, Mutasim Khamis ${ }^{4}$ \\ Multimedia University, Cyberjaya, Malaysia \\ University Malaysia Kelantan, Malayisa \\ University of Malaya, Kuala Lumpur, Malaysia \\ International Islamic University Malaysia
}

Introduction: The recent outbreak of novel corona virus known as COVID-19, has caused over 556.335 deaths, left more than 12 million infected people worldwide by $11^{\text {th }}$ of July 2020 (Organization, 2020a), in addition to global negative impact on nearly most life sectors. Media played -and still- a vital role in the containment of this global health threat by spreading the essential knowledge and awareness between people. Comparing to its neighbours, Malaysia seems to have good score in the battle of COVID-19. With 8,815 confirmed cases, 8,562 total discharged cases and 123 deaths by $21^{\text {th }}$ of July 2020 (Malaysia, 2020), it was interesting to study the role of media in shaping people's awareness during the current global crisis to face the danger of such virus on the national level. Aim: To analyse and understand the Malaysian government role in shaping people's awareness toward COVID-19. Method: Authors are tracking and analysing the ministerial media arms role in handling the situation, based on the official data and statements released by the national news agency, Bernama. This article is divided into three main parts as it discusses the role of three specific governmental official; Prime Minister, General Director of Ministry of Health, and Senior Security Minister, Findings: The Malaysian governmental officials namely; Prime Minister, General Director of Ministry of Health, and Senior Security Minister followed a successful strategy during COVID19 pandemic to rely a part on people's awareness by providing them with the accurate information to avoid the viral spread of fake news. Conclusion: Malaysia was able to contain the pandemic on the national level powered by people's awareness.

Keywords: COVID-19, Malaysia, Government, Media, Awareness 


\section{Kresna Social Science and Humanities Research \\ Proceedings of the International Conference On Ummah: Digital Innovation, Humanities And Economy (ICU: DIHEc) 2020 https://doi.10.30874/ksshr.68}

\section{Introduction}

Recently, a novel coronavirus causing severe respiratory tract infections in humans became a global health concern. The virus was first identified in Wuhan, Hubei Province, China by the Chinese health authorities in December 2019 (Amodio, Vitale, Cimino, Casuccio, \& Tramuto, 2020). The outbreak of the novel coronavirus led to a global panic due to its fatal nature all over the world (Karim, Haque, Anis, Ulfy, \& Yournal, 2020). There was a propagating number of deaths in all countries across the world including Malaysia. In Malaysia, cases were detected by the end of January 2020, and the numbers were jumped to hundreds by the end of March 2020 (Tay et al., 2020). Malaysia was a distinguished example of the high level of awareness and knowledge trying to stop the virus spread and to overcome the negative effects caused by the pandemic. The knowledge, attitudes and practices shape the awareness toward COVID-19 which contributes to determining the Malaysian society's readiness to accept behavioural change measures regulated by authorities (Mohamad, Azlan, Hamzah, Tham, \& Ayub, 2020). Malaysia took various measurements which marked it among the top five successful countries as the Malaysian prime minister mentioned. Malaysia witnessed a governmental change at March 2020, however its authorities continued playing a vital role in the global crisis. In this article, authors discuss the vital role of certain governmental authorities such as Ministry of Health, National Security Council and Prime Minister Office to contain the pandemic in Malaysia. This article focuses more on the ministerial media role to improve people's awareness as a critical point in the battle against the pandemic. Malaysian government has approved 'Daily Conference Briefing' style as its main communication method with the public during the time of pandemic. Daily conferences from different governmental bodies aimed to update people with latest information and current virus situation in the country, tackle fake 


\section{Kresna Social Science and Humanities Research \\ Proceedings of the International Conference On Ummah: \\ Digital Innovation, Humanities And Economy (ICU: DIHEc) 2020 \\ https://doi.10.30874/ksshr.68}

news and false claims, and introduce the new normal rules and regulations. As the Malaysian government announced that it successfully controlled the spread of the novel corona virus and was able to flatten the COVID-19 curve, it was important to analyze the role of the main authorities on the level of media exposure to understand how Malaysia reached that level. Therefore, authors tried to answer the question: To what extent Malaysian government was able to shape people's awareness regarding COVID-19?

\section{Literature Review}

The literature of this article mainly depends on the official data, governmental statements, authorities' decisions that were announced by the National News Agency 'Bernama' as an official source. The rapid spread of novel coronavirus disease (COVID-19) has significant effects on all life aspects worldwide. Therefore, the article gives a comprehensive review of the crucial role played by Malaysian governmental institutions including Ministry of Health, National Security Council and Prime Minister office aiming to face COVID-19 crisis and to raise knowledge among Malaysian people to be aware enough to pass this difficult time. Out of our analysis and daily media conferences tracking, authors found that there was a common concept between the governmental officials to appreciate people's support and awareness and highlight Malaysian front liners' sacrifices during the national battle against the virus. Prime Minister Tan Sri Muhyiddin Yassin, Health director-general Datuk Dr Noor Hisham Abdullah, and Senior Security Minister and Defence Minister Datuk Seri Ismail Sabri Yaakob repeatedly highlighted the vital role played by health and security front liners.

The first appearance of the sudden outbreak of coronavirus infection occurred in Wuhan, Hubei Province, China in December 2019, then it spread across China and beyond (Huang et al., 


\section{Kresna Social Science and Humanities Research \\ Proceedings of the International Conference On Ummah: Digital Innovation, Humanities And Economy (ICU: DIHEc) 2020 https://doi.10.30874/ksshr.68}

2020). The rapid reaction of the Chinese clinical, scientific and public health communities enabled the fast recognition of the disease and the primary understanding of the infection epidemiology. A group of international experts collaborating with a range of specializations have worked hard with Chinese counterparts in order to contain the hazardous outbreak (Organization, 2020b). On January $30^{\text {th }}$ 2020, the World Health Organization (WHO) announced the virus outbreak a Public Health Emergency of International Concern (Organization, 2020c). The Health Organization officially called the disease triggered by the novel coronavirus as coronavirus disease 2019 (COVID-19) On February $12^{\text {th }} 2020$ (Wehrey, 2012).

Public awareness is an important factor in the successful management of the spread of infectious diseases. Awareness can be presented into individual actions such as increased attention to hygiene and avoiding crowded areas which in turn can reduce disease spread obviously. Awareness also can be presented into the rapid identification of patients, treatment of new cases and facilitating collective responses including closures of schools and transit systems (Bootsma \& Ferguson, 2007). Digital technology means also help to convey accurate information which enable individuals to protect themselves against any pandemic (Granell, Gómez, \& Arenas, 2013). Moreover, media has the ability to spread knowledge faster providing an opportunity for individuals and communities to be concerned about the latest governmental guidelines and public restrictions. Media creates awareness defined by three features; early awareness, strong awareness magnitude and high retention of awareness (Chen, Xu, Paris, Reeson, \& Li, 2020).

Malaysia announced, on $25^{\text {th }}$ January 2020, detecting the first three COVID-19 cases, and by $20^{\text {th }}$ July 2020, cumulative figure of positive cases reached 8,800 , with 123 deaths or 1.4 per 


\section{Kresna Social Science and Humanities Research \\ Proceedings of the International Conference On Ummah: Digital Innovation, Humanities And Economy (ICU: DIHEc) 2020 https://doi.10.30874/ksshr.68}

cent of the total cases. These numbers within 6 months are giving good impression about the national situation compared to some neighbour countries. The peak of infection was recorded by the end of May and beginning of June, when Malaysia recorded 271 new cases in a single day, however daily rate declined to single and double digits since that time with low local infection rate. Despite the political crisis that ended up with changing the federal government on $29^{\text {th }}$ February, Malaysia was able to implement various decisions on different levels to face the pandemic. Even after easing restrictions, authorities continued advising the public to be responsible enough in the new normal era and follow government guidelines. Different governmental bodies expressed gratitude to the medical front liners and thanked their families for understanding and appreciating their family members' jobs as well as media members (Palansamy, 2020).

Bernama and the other Malaysian news have highlighted the first 100 days under MCO, and some ministers appeared in media conferences to show their efforts to tackle the pandemic negative effect on the economic, social and health levels. The MCO that took effect on March 18, was an essential reason why Malaysia succeeded in flattening COVID-19's infection curve, MCO, according to several government officials, was able to reduce the virus transmission locally.

\subsection{Prime Minister}

On $16^{\text {th }}$ March, Malaysian government announced the enforcement of the Movement Control Order (MCO) starting from March 18 on the national level in order to curb the transmission of COVID-19 and increase social distancing, with closure of the country's borders. Prime Minister Tan Sri Muhyiddin Yassin used to announce the updates and decisions related to the 


\section{Kresna Social Science and Humanities Research \\ Proceedings of the International Conference On Ummah: \\ Digital Innovation, Humanities And Economy (ICU: DIHEc) 2020 \\ https://doi.10.30874/ksshr.68}

$\mathrm{MCO}$ and economic support during the pandemic regularly. PM announced the extension of MCO three times, each for another two-week period. On $13^{\text {th }}$ May, Malaysia witnessed a new phase called the Conditional Movement Control Order (CMCO). Prime Minister played a significant role in the mission of raising people's awareness of the economic and social challenges caused by the global pandemic and how the government is dealing with it. He made number of important decisions and public announcements on various levels, including RM250 billion Economic Stimulus Package (Prihatin Rakyat) aiming to support all segments of Malaysians and another Package of RM10 billion for Small and Medium Enterprises (SMEs). Muhyiddin at every conference urged Malaysians to follow the healthcare restrictions and MCO guidelines.

For encouraging people to adhere to the governmental guidelines, empowering people and economy and relieving the crisis heavy pain, PM announced a short-term National Economic Recovery Plan (PENJANA) worth RM35 billion. Meanwhile, Muhyiddin announced entering a new phase called the Recovery Movement Control Order (RMCO) which started from $10^{\text {th }}$ June and continued until $31^{\text {st }}$ August, allowing people to return back to their normal life with the standard operating procedures (SOP), including wearing of face masks, social distancing and frequent washing of hands. RMCO has considered a sign of recovery and controlled situation as the country has succeeded in flattening the virus infection curve. However, government noticed that number of daily infection rate raised to two digits and the risk of another infection wave became possible, then Prime Minister addressed the nation, on 20 July, to warn people another national lockdown and said "I am sure all of you do not want the government to reimpose a lockdown that is necessitated by a surge in COVID-19 cases. I pray and hope that we would not reach that stage". In this special address, Muhyiddin explained 


\section{Kresna Social Science and Humanities Research \\ Proceedings of the International Conference On Ummah: \\ Digital Innovation, Humanities And Economy (ICU: DIHEc) 2020 \\ https://doi.10.30874/ksshr.68}

how the economy was badly affected by the lockdown and how another lockdown will lead to worst scenario, expecting that Malaysia would lose at least RM2 billion a day. He spoke in numbers about the governmental efforts and stimulus packages to help people and businesses to face the impact of the pandemic. He was aiming to remind people that the deadly virus is not over yet, and urged them to follow SOP as many people 'had gone back to shaking hands and hugging when greeting their friends and relatives'. He also declared that punishment is an option to enforce regulations with imposing 'heavier fines' on SOP violators

\subsection{Health director-general}

The most significant media role of the Malaysian Ministry of Health $(\mathrm{MoH})$, was -and still- its daily media conferences where Health director-general (DG) Datuk Dr Noor Hisham Abdullah appeared every afternoon on television to announce the updates of COVID-19. Daily conference is the official source for people who are seeking the latest COVID-19 new cases, recoveries and statistics of infections on the national level. On the first day of the Movement Control Order (MCO), $18^{\text {th }}$ of March 2020, Health ministry urged all Malaysians to follow the Movement Control Order seriously and stay at home. It tried to simplify the call by saying "stay at home and distance yourself from others" on its official social media pages, so all people can understand the situation. Health DG also urged the public to help the authorities and break COVID-19 transmission chain.

Health DG warned Malaysians from public gathering such as Ramadan Bazaar during MCO, and urged people to adapt to the new normal practices expecting that mass gatherings will be not allowed even after removal of MCO. 


\section{Kresna Social Science and Humanities Research}

Proceedings of the International Conference On Ummah: Digital Innovation, Humanities And Economy (ICU: DIHEc) 2020 https://doi.10.30874/ksshr.68

The Malaysian Health Ministry undertook strict precautions at the high-risk regions to prevent the fast spread of COVID-19 virus and directed huge disinfection processes to these regions as well as malls. It followed a specific treatment plan by considering three specific medications to treat patients with infection symptoms. The ministry also provided Malaysian people and foreigners with COVID-19 test free of charge. It also called the participants in Tabligh gathering held at the Sri Petaling Mosque whose number exceeded 15 thousand participants, which was a main infection cluster, to do the test for free. Within few days from that call, health ministry announced that more than 10 thousand attendees have been tested for COVID-19. It was also announced that the ministry invited the illegal immigrants to do the test without any fear to be arrested. Moreover, the ministry increased the number of health workers and requested more volunteers to help overcome the pandemic. Free food and accommodations were offered to the doctors and nurses in the front lines. In addition, the ministry equipped the closed football playgrounds and public halls to receive patients in case of the sudden increase in their numbers. The ministry sent the Malaysian travellers who were recently abroad directly to quarantine centres as well.

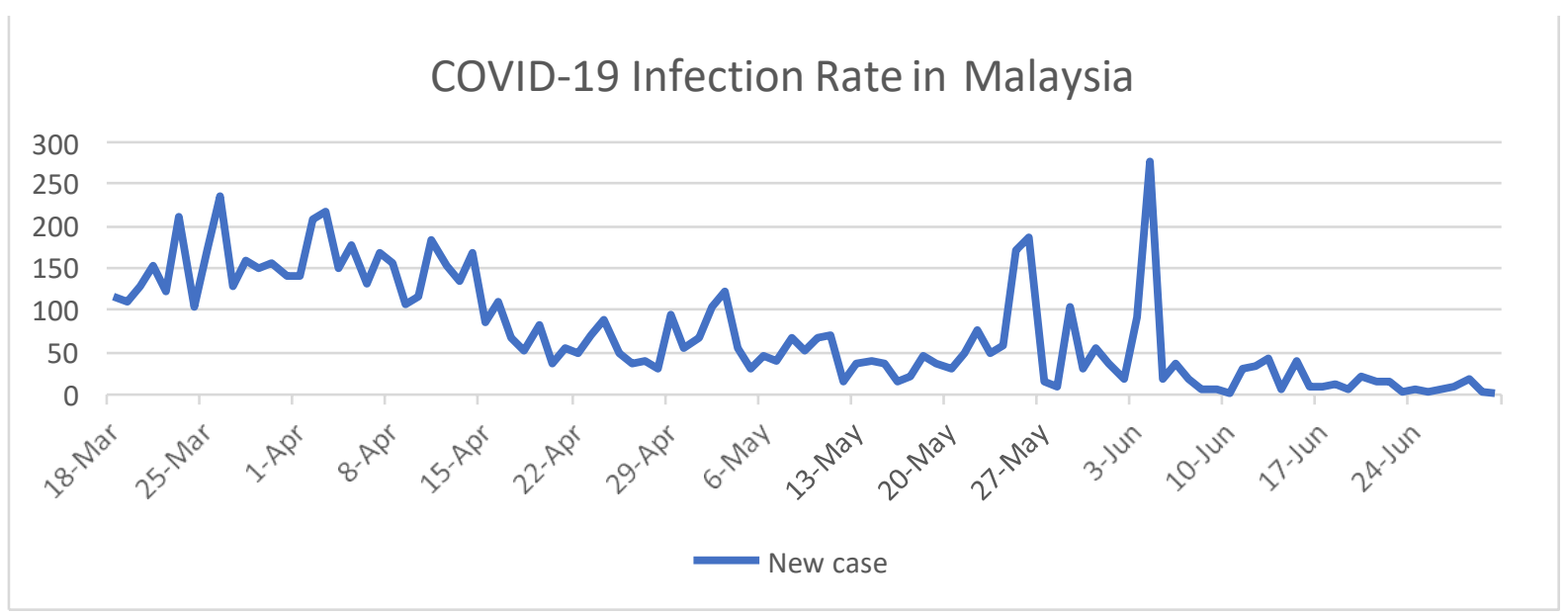




\section{Kresna Social Science and Humanities Research}

Proceedings of the International Conference On Ummah: Digital Innovation, Humanities And Economy (ICU: DIHEc) 2020

https://doi.10.30874/ksshr.68

After 100 days of MCO, Health director-general announced that Malaysia has entered recovery phase as the new daily infection rate dropped to double digits and death rate became less than $1.4 \%$. Hisham also called people for strong adherence to the standard operating procedures and strict following for the new normal guidelines to ensure effective and successful RMCO (Bernama, 2020). As per figure 1, daily infection rate has significantly dropped under the $\mathrm{MCO}$, the same was the death rate as shown in figure 2.

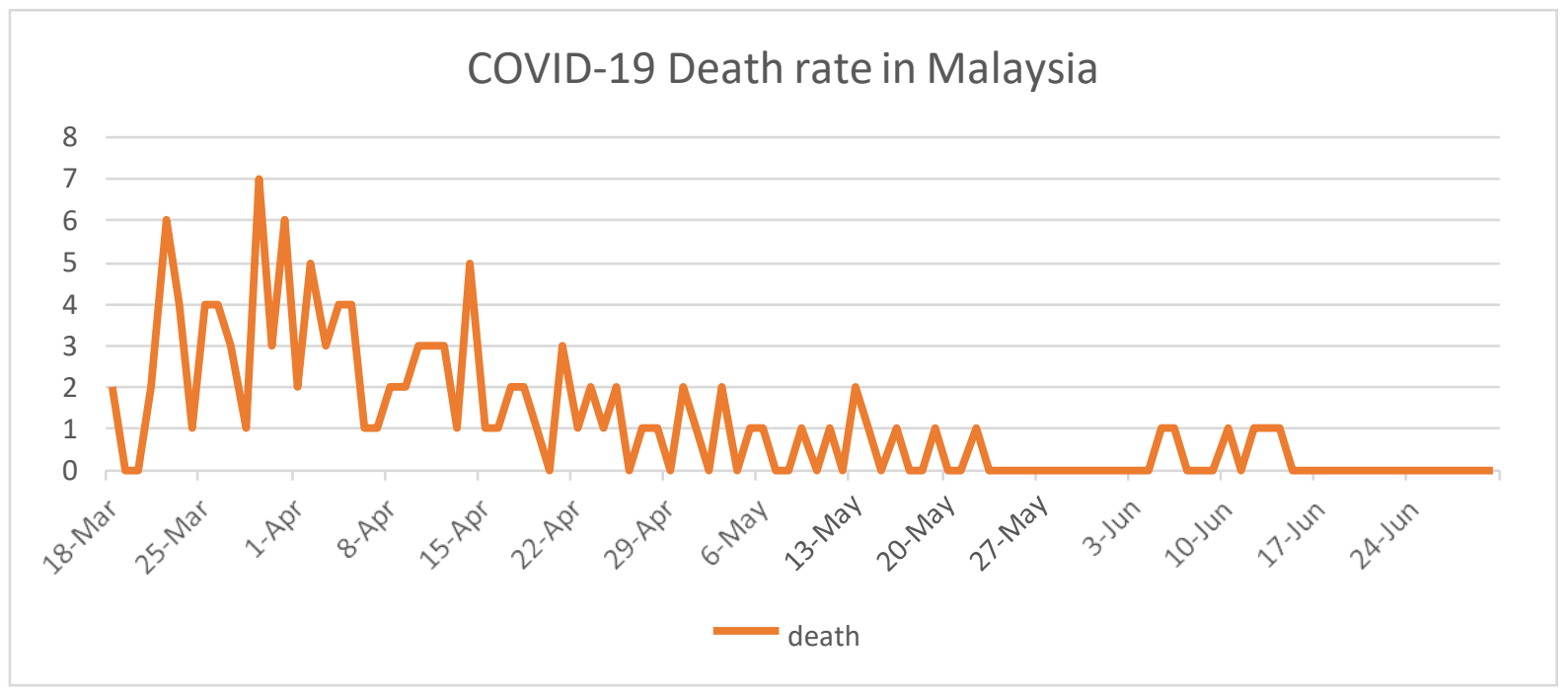

Figure 2

He insisted that the significant result was a result of good behaviour of people and the whole community, in addition to the increased capacity of hospitals, laboratories and clinics and borders closure. On the other hand, he mentioned that the decision of replacing home quarantine with 14-day mandatory quarantine at the quarantine stations was made to avoid another new wave of infection, after recording increased number of MCO violations and detecting 13 new clusters. He also explained that the less adherence to the standard operating procedures (SOP) will lead to increased new COVID-19 cases, and clarified that the direct contact with persons coming from abroad during home quarantine may cause infection transmission to their family members. 


\section{Kresna Social Science and Humanities Research \\ Proceedings of the International Conference On Ummah: Digital Innovation, Humanities And Economy (ICU: DIHEc) 2020 https://doi.10.30874/ksshr.68}

\subsection{Senior Security Minister}

There was another daily media briefing conference on security decisions and updates related to the various movement control orders. It was daily for three months, then became three times a week; on Mondays, Wednesdays and Fridays. The person who appeared daily to enrich people with new Standard Operating Procedures (SOP) was Senior Security Minister and Defence Minister Datuk Seri Ismail Sabri Yaakob. In his last daily conference, he stated "Time indeed flies fast without our realising and it has now been three months I have been with you all, ladies and gentlemen, daily, at 2pm" (Palansamy, 2020). Ismail was -and still- the official source of COVID-19 security related matters, and his daily briefing is an extremely important meal for Malaysians and foreigners staying in Malaysia. This media conference is playing an effective role in challenging fake news related to the pandemic and providing detailed guidelines for each Movement Control Orders and Recovery Movement Control Order. National security daily conference is considered as a campaign to raise awareness on the new normal and to show people the importance of self-discipline.

In order to enforce MCO application, the government imposed RM1,000 fine on MCO offenders, and police officers allowed to use their discretion to either issue a compound against MCO violators or send them to court where a jail sentence will then be determined, according to Ismail Sabri (Chan, 2020).

On June 14, Ismail Sabri said that Malaysia has been recognised as one of the top five nations globally for being able to control the spread of virus, and added that the global recognition has been achieved by people's well-acceptance of the governmental decisions and measurements. 


\section{Kresna Social Science and Humanities Research \\ Proceedings of the International Conference On Ummah: \\ Digital Innovation, Humanities And Economy (ICU: DIHEc) 2020 \\ https://doi.10.30874/ksshr.68}

He stated that public approval was an important element to achieve a deserved winning in the battle against COVID-19.

However, during RMCO, Sabri clarified that police will not warn violators anymore. Instead, authorities will take immediate legal actions against them due to the increased number of flouting cases of RMCO. He also urged food restaurants and premises owners to fully comply with the SOP and enforce social distancing to avoid facing stern action. He also announced that all Malaysians and foreigners arriving from abroad will undergo 14-days mandatory quarantine instead of home quarantine.

As a senior security minister, Ismail Sabri used to update the public with the new daily total of arrested individuals across the country for flouting (MCO), as Malaysia deployed more than 1,520 roadblocks to check vehicles and take action against people who disregard the MCO. Security check points and lockdown enforcement were a shared tasks between the Royal Malaysia Police (PDRM) and Malaysian Armed Forces (ATM).

On June 10, Bukit Aman Criminal Investigation Department announced that total number of individuals have been arrested due to $\mathrm{MCO}$ and $\mathrm{CMCO}$ various offences between March 18 and June 9, was 26,366. Out of this number, Royal Malaysia Police had charged 20,720 individuals. Based on information from both Home Ministry (KDN) and Ministry of Health (MOH), Malaysian authorities collected more than RM5,928,000 total fine for defying MCO, from companies and individuals between March and June 2020. Fine and jail were effective actions to enforce SOP and push public to comply with the guidelines during MCO.

Another side effect of his daily conference that has been addressed by social media users, was the wide range of batik (traditional) attire because Sabri seems to have unique and colourful designs of shirts in his daily press conference. This event created a new level of interaction 


\section{Kresna Social Science and Humanities Research \\ Proceedings of the International Conference On Ummah: \\ Digital Innovation, Humanities And Economy (ICU: DIHEc) 2020 \\ https://doi.10.30874/ksshr.68}

between Ismail Sabri and the internet users, as he thanked Malaysians for their kind words and wished them a blessed Ramadan.

Regarding foreigners in Malaysia, it was an essential part of the security daily conferences and Senior Minister used to announce the decisions related to foreigners, refugee and undocumented immigrants. He announced, for example, that Malaysia is going to deport detained illegal migrants to their home countries starting from June 6. However, Malaysia faced critics regarding how it managed undocumented foreign workers especially in the detention centres during its fight against the virus. Sabri in different daily briefings denied the claim that Malaysia discriminated against illegal immigrants.

\section{Discussion and Conclusion}

The daily media conference by the Malaysian Health Ministry, was -and still- the main official and most accurate source of information about the pandemic situation on the national level. This daily conference played a vital role in shaping people's awareness and delivered a highquality instruction helped in the containment of the global crisis. It also, combined with the other regular and daily conferences from National security councils and other authorities, were able to dismiss the fake news and incorrect information. The official daily conferences were able to highlight the significant precautions taken by the Malaysian government to prevent COVID-19 transmission. The main governmental decision was The Movement Control Order and it was able to lower the number of new cases and played effective role in containing the pandemic on the national level. Ministerial media arms were -and still- responsible for shaping the community awareness and encouraging people to comply with the standard operating procedures SOP. The efforts and daily or regular appearance of the Malaysian Prime Minister, 


\section{Kresna Social Science and Humanities Research \\ Proceedings of the International Conference On Ummah: Digital Innovation, Humanities And Economy (ICU: DIHEc) 2020 \\ https://doi.10.30874/ksshr.68}

General Director of Ministry of Health and Senior Security Minister, played vital role in the fight against the global health crisis and led Malaysia to enter the recovery phase with lower daily infection rate. Therefore, governmental strategy in the time of pandemics have to rely in a part on the people's awareness by getting directly in touch with community and answer their questions about the situation to avoid the viral spread of fake news and myths that can lead to another crisis.

\section{References:}

Amodio, E., Vitale, F., Cimino, L., Casuccio, A., \& Tramuto, F. (2020). Outbreak of novel coronavirus (SARS-Cov-2): first evidences from international scientific literature and pending questions. Paper presented at the Healthcare.

Bernama. (2020). 100 days of MCO: Malaysia's success in flattening the Covid-19 infection curve. The Star. Retrieved from https://www.thestar.com.my/news/nation/2020/06/25/100-days-of-mco-malaysia039ssuccess-in-flattening-the-COVID-19-infection-curve

Bootsma, M. C., \& Ferguson, N. M. J. P. o. t. N. A. o. S. (2007). The effect of public health measures on the 1918 influenza pandemic in US cities. 104(18), 7588-7593.

Chan, D. (2020). RM1,000 fine for MCO violators to stay, says Ismail Sabri. New Straits Times. Retrieved from https://www.nst.com.my/news/nation/2020/04/583631/rm1000fine-mco-violators-stay-says-ismail-sabri

Chen, H., Xu, W., Paris, C., Reeson, A., \& Li, X. J. m. (2020). Social distance and SARS memory: impact on the public awareness of 2019 novel coronavirus (COVID-19) outbreak.

Granell, C., Gómez, S., \& Arenas, A. J. P. r. 1. (2013). Dynamical interplay between awareness and epidemic spreading in multiplex networks. 111(12), 128701.

Huang, C., Wang, Y., Li, X., Ren, L., Zhao, J., Hu, Y., . . Gu, X. J. T. 1. (2020). Clinical features of patients infected with 2019 novel coronavirus in Wuhan, China. 395(10223), 497-506.

Karim, W., Haque, A., Anis, Z., Ulfy, M. A. J. I. T., \& Yournal, H. (2020). The movement control order (mco) for covid-19 crisis and its impact on tourism and hospitality sector in malaysia. 3(2), 1-7.

Malaysia, M. o. H.-. (2020). Situasi Semasa Pandemik COVID-19 Di Malaysia. Retrieved from http://covid-19.moh.gov.my/

Mohamad, E. M., Azlan, A. A., Hamzah, M. R., Tham, J. S., \& Ayub, S. H. J. m. (2020). Public knowledge, attitudes and practices towards COVID-19: A cross-sectional study in Malaysia.

Organization, W. H. (2020a). Coronavirus Disease 2019 (COVID-19): situation report-137.

Organization, W. H. (2020b). Coronavirus Disease 2019 (COVID-19): situation report-30. 


\section{Kresna Social Science and Humanities Research \\ Proceedings of the International Conference On Ummah: Digital Innovation, Humanities And Economy (ICU: DIHEc) 2020 https://doi.10.30874/ksshr.68}

Organization, W. H. (2020c). Statement on the second meeting of the International Health Regulations (2005) Emergency Committee regarding the outbreak of novel coronavirus (2019-nCoV). Retrieved from https://www.who.int/news-room/detail/30-01-2020statement-on-the-second-meeting-ofthe-international-health-regulations-(2005)emergency-committee-regarding-the-outbreak-of-novel-coronavirus-(2019-ncov)

Palansamy, Y. (2020). Announcing end to daily security briefings, Ismail Sabri jokes that Malaysians won't get to see his colourful batik shirts. Malay Mail. Retrieved from malaymail.com/news/malaysia/2020/06/14/announcing-end-to-daily-securitybriefings-ismail-sabri-jokes-that-malaysia/1875340

Tay, K., Kamarul, T., Lok, W., Mansor, M., Li, X., Wong, J., \& Saw, A. J. M. O. J. (2020). COVID-19 in Singapore and Malaysia: rising to the challenges of orthopaedic practice in an evolving pandemic. 14(2).

Wehrey, F. a. (2012). The politics of sectarianism in the Gulf : Bahrain, Saudi Arabia, and Kuwait, 2003-2011. (Thesis (Ph.D.)), Oxford University, 